\title{
LIMNOLOGICAL SURVEY OF DHAKA-NARAYANGANJ-DEMRA (DND) DAM AREA WETLANDS
}

\author{
AHM Shafiullah Habib, Mahiuddin Sarker ${ }^{*}$, Md. Gias Uddin \\ Shimu Akter and M. Niamul Naser ${ }^{2}$ \\ Department of Zoology, Jagannath University, Dhaka-1100, Bangladesh
}

\begin{abstract}
Present investigation was conducted to assess the physicochemical characteristics of water and its suitability for fish production at DhakaNarayanganj-Demra (DND) dam wetlands. Data were collected at eight points of the study area between March 2014and February 2015on temperature, transparency, $\mathrm{pH}$, dissolved oxygen (DO) and free carbon dioxide $\left(\mathrm{CO}_{2}\right)$ in the water. The average maximum water temperature, transparency, $\mathrm{pH}, \mathrm{DO}$, free $\mathrm{CO}_{2}$, hardness were recorded as $34.6 \pm 0.4^{\circ} \mathrm{C}, 40.3 \pm 0.8 \mathrm{~cm}, 7.9 \pm 0.06,7.6 \pm 0.4 \mathrm{mgL}^{-}$ ${ }^{1}, 85.6 \pm 6.6 \mathrm{mgL}^{-1}$ and $491.2 \pm 76 \mathrm{mgL}^{-1}$ while minimum average were found as $26.3 \pm 1.0^{\circ} \mathrm{C}, 7.1 \pm 0.2 \mathrm{~cm}, 7.4 \pm 0.05,5.9 \pm 0.3 \mathrm{mgL}^{-1}, 11.9 \pm 0.8 \mathrm{mgL}^{-1}$ and $87.6 \pm 11.3$ $\mathrm{mgL}^{-1}$ respectively.All the water parameters were found in favourable condition for optimum freshwater fish production with some modification. This study can be the baseline data toward fresh fish supply and production prospect in the Dhaka city at wetland of the DND canal area.
\end{abstract}

Keywords: DND canal, physicochemical parameters, limnology, fish culture, Dhaka, Bangladesh

\section{INTRODUCTION}

Water is the main vector for all development activities and is integrated related with all ecological and societal processes (Viessman and Hammer, 1998).Good water denotes the component of water which are essential for optimum growth of aquatic organisms (Ehiagbonare and Ogundiran, 2010).Water quality guidelines include basic scientific information about water quality parameters and ecologically relevant toxicological threshold values to protect specific water uses. Surface water quality of the rivers of Bangladesh becoming highly polluted day by day (DoE, 1993). The human activities release large number of pollutants into the water bodies (Kocaoba and Akcin, 2005). Physical and chemical parameters that influence the aquatic environment are temperature, transparency, $\mathrm{pH}$, dissolved oxygen (DO), free carbon dioxide $\left(\mathrm{CO}_{2}\right)$ and hardness. In addition, total alkalinity, biochemical oxygen demand (BOD), chemical oxygen demand (COD), total dissolved solids (TDS), total suspended solids (TSS), nitrite, ammonia, hydrogen sulphide $\left(\mathrm{H}_{2} \mathrm{~S}\right)$, phosphate etc are also important physicochemical parameters that influence the water quality. These parameters limit the growth and survival of aquatic organisms. Bad water qualities may be caused by low water flow, municipal effluents and industrial discharge etc. Water parameters has great impact on survival, growth, reproduction and distribution of fishes (Deepak and Singh, 2014). Any adverse environmental condition usually affects the life of fishes in the water body.

\footnotetext{
*Author for corresponding:, mahiuddin0785@gmail.com, 1 Sejong University, Seoul, South Korea, 2Department of Zoology, University of Dhaka, Dhaka 1000, Bangladesh
}

C2020 Zoological Society of Bangladesh DOI: https://doi.org/10.3329/bjz.v48i1.47879 
In reality, whole of the aquatic life in any water body is controlled by the interaction of a number of physical and chemical conditions. Gross physicochemical characteristics of DND canal have been reported by several workers earlier. It is important for better understand this small sized body of water especially with regard to changes in water quality as a result of run off or human activities. Water is the habitation of the fish and

its quality is commonly avoided until it effects on fish production. Canal habitats can easily be exploited by managing the water parameters for an optimum environment that yield high amount of fish. DND dam area is located in the southeast suburb of Dhaka Metropolitan city and is stretched over Demra and Shampur Thana of Dhaka district and Shiddirganj and Fatullah Thana of Narayanganj district. This dam was started to construct in 1964 and completed in 1968 aimed to control flood for 4,860 ha land (Banglapedia, 2006). This study focuses on evaluation of some physicochemical parameters and suitability of DND canal water bodies for fish production. No such research has been done yet on fish culture of these places except Habib et al.(2013). This is the further and extensive study of the previous work.

\section{MATERIAL AND METHODS}

Study area and Sampling stations: Dhaka-Chittagong highway passes through the DND dam area at Jatrabari point to Siddhirganj. Demra road covers another part of the area and in the south is the Buriganga and the Shitalakshya River in the eastern side. In the monsoon the whole area becomes a vast waterbody and water stands for 4-6 months temporarily in the area. Most of the dam is used as a road to communicate Narayanganj with Dhaka city. For the present study eight sampling spots were selected where the small canal and huge water body located in the DND dam area. The sampling points were Council(S1: $23^{\circ} 42^{\prime} 56.22^{\prime \prime} \mathrm{N}$ and 90 $\left.{ }^{\circ} 27^{\prime} 42.37^{\prime \prime} \mathrm{E}\right)$, Ranimohal (S2: $23^{\circ} 42^{\prime} 46.05^{\prime \prime} \mathrm{N}$ and $\left.90^{\circ} 29^{\prime} 53.27^{\prime \prime} \mathrm{E}\right)$, Chittagong $\operatorname{Road}\left(\mathrm{S} 3: 23^{\circ} 41^{\prime} 57.02^{\prime \prime} \mathrm{N}\right.$ and $\left.90^{\circ} 30^{\prime} 28.20^{\prime \prime} \mathrm{E}\right)$,

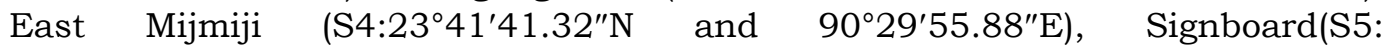
$23^{\circ} 41^{\prime} 44.02^{\prime \prime} \mathrm{N}$ and $\left.90^{\circ} 28^{\prime} 57.27^{\prime \prime} \mathrm{E}\right)$, Lama Para (S6:23 $39^{\prime} 03.46^{\prime \prime} \mathrm{N}$ and $\left.90^{\circ} 29^{\prime} 32.41^{\prime \prime} \mathrm{E}\right)$, Afaz Nagar(S7:23 $39^{\prime} 03.4^{\prime \prime} \mathrm{N}$ and $\left.90^{\circ} 28^{\prime} 57.60^{\prime \prime} \mathrm{E}\right)$ and Pagla (S8: $23^{\circ} 39^{\prime} 39.82^{\prime \prime} \mathrm{N}$ and $90^{\circ} 27^{\prime} 25.91^{\prime \prime} \mathrm{E}$ ). Among the eight spots, three sites (S1, S2 and S5) were under Dhaka district and rest fives were under Narayanganj district (Fig. 1). According to Bangladesh Bureau of Statistics (BBS, 2015), the study period was divided into three seasons viz. March to June as summer, July to October as monsoon and November to February as winter.

Sample collection and analyses: Samples were collected from eight sampling sites between March 2014 and February 2015. In order to get the information about the quality of water body in DND area samples were usually collected in the last week of each month between 6 am and 9 am. Water samples were collected in dark coloured bottles with stopper from sub-surface about 10 to $15 \mathrm{~cm}$ below the top of the water surface from different sampling points. Before sample collection, all bottles were washed with dilute acid followed by distilled water and were dried in sun light. At the time of taking final water 
samples, the bottles were again rinsed three times with the water to be collected from the sites.

The sample bottles were labelled with date and sampling sites. The sample waters were bottled carefully avoiding air bubble into it. The location of the sample sites were recorded with a GPS device (GARMIN e-trax) at time of sampling. Samples were carried from sampling sites to the laboratory by covering with black coloured bag. Six water quality parameters namely temperature, transparency, $\mathrm{pH}$, free $\mathrm{CO}_{2}, \mathrm{DO}$, and hardness have been recorded for this particular study. Water temperature was determined with the help of a mercury thermometer. To get the reading of temperature the thermometer was dipped into the water at consistent surface depth $10 \mathrm{~cm}$ and record the value

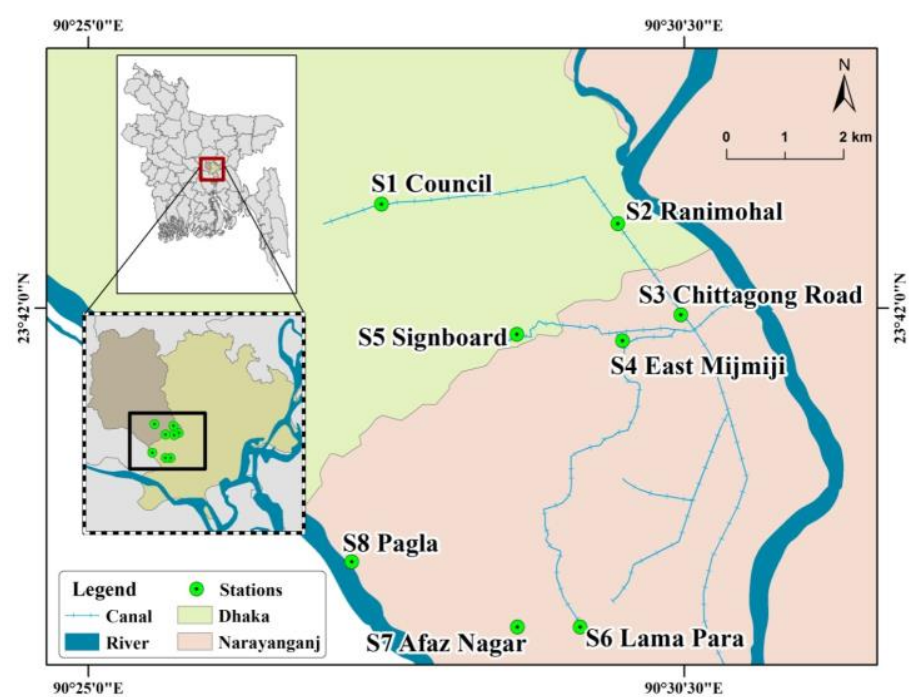

Fig.1. Map showing eight sampling sites of the DND dam area - Council (S1), Ranimohal (S2), Chittagong Road(S3),East Mijmiji (S4), Signboard(S5), Lama Para (S6), Afaz Nagar (S7) and Pagla (S8).

directly. The transparency of the water was measured with a Secchi disc of 25 $\mathrm{cm}$ in diameter (painted black and white on the upper surface) and calculated by the following formula:

$\mathrm{T}=\frac{X+Y}{2}$

Where, $T$ is the transparency of water in centimetre,

$X$ is the depth of water at which the disc became invisible, and

$Y$ is the depth of water at which the disc reappeared while pulling the rope upward.

$\mathrm{pH}$ of water was measured at the time of sampling site by Hanna Combo meter(Model HI 98129) and using buffer solution which $\mathrm{pH}$ value was 7.0 
accordance to standard method. For analysis of DO, water samples were collected in separate sampling bottles and analyzed in the laboratory. DO and free $\mathrm{CO}_{2}$ were measured by titrimetric method. Hardness was measured by complex metric titration method. Dissolved oxygen (DO, $\mathrm{mgL}^{-1}$ ) was measured following Winkler-Azide method. Firstly $2 \mathrm{ml}$ of manganese (II) sulfate solution was added immediatelyto $300 \mathrm{ml}$ sample water just below the surface and mixed carefully without letting in air on spot. Then $2 \mathrm{ml}$ of alkali iodide-azide was added and again mixed as earlier. A brownish-orange cloud of precipitate or floc was appeared, if oxygen present. Let the floc settle to the bottom and mixed the sample by turning it upside down several times and let it settled again. After that $2 \mathrm{ml}$ of concentrated sulphuric acid was added to the sample just above the surface of the sample with a pipette held. Stopper and invert several times to dissolve the floc with care. At this point, the sample is 'fixed' and can be stored for up to 8 hours if kept in a cool and dark place. In the laboratory,201 $\mathrm{ml}$ of the above sample water was taken to a conical flask and titrate with sodium thiosulphate until appear a pale straw colour. Now $2 \mathrm{ml}$ of starch solution was added to it and the sample water turned to blue. This blue sample was titrated again with thiosulphate until it turned clear. At this point the reading was recorded and DO was calculated as the burette reading of sodium-thiosulphate used in the whole titration process. Free carbon dioxide $\left(\mathrm{CO}_{2}\right)$ was measured by titrimetric method using in $\mathrm{N} / 44 \mathrm{NaOH}$ and phenolphthalein indicator(Hargis, 1988). First, $100 \mathrm{ml}$ of sample water is taken to a conical flask and added 10 drops of phenolphthalein indicator to it. The burette was then filled with $\mathrm{NaOH}$ solution. Sample water was titrate with $\mathrm{NaOH}$ until the water turned to light pink colour. The difference in millilitres between the first and second reading of the burette was used to calculate the $\mathrm{CO}_{2}$ present in the sample water. Hardness $\left(\mathrm{mgL}^{-1}\right)$ is the reading of Ethylenediaminetetraacetic acid (EDTA) solution(HI3812-0), hardness buffer, calamite indicator from HANNA Instrument (Hardness Test Kit) using standard method (HANNA Instrument, 2009).The amount of used EDTA was multiplied by 300 to estimate the hardness of water.

Standard deviation and standard error were analyzed by MS Office Excel 2013 programme.

\section{RESULTS AND DISCUSSION}

Water temperature: Maximum average water temperature was recorded 34. $6 \pm 0.4^{\circ} \mathrm{Cin}$ Lama Para(S6) and minimum, $26.3 \pm 1^{\circ} \mathrm{C}$ in East Mijmiji (S4) among the eight sites(Table1, Fig.2).Maximum seasonal mean water temperature was $30.75 \pm 0.76^{\circ} \mathrm{C}$ in summer and minimum, $18 \pm 1.45^{\circ} \mathrm{C}$ in winter(Fig. 2). The highest temperature was recorded as $31.88 \pm 0.449^{\circ} \mathrm{C}$ in July and lowest, $22.13 \pm 1.754^{\circ} \mathrm{C}$ in January (Table 2). The solubility of gases in water are controlled by temperature and the reaction rate of chemicals, the toxicity of ammonia and of chemotherapeutics to fish. According to Delince(1992),30 $-35^{\circ} \mathrm{C}$ temperature is tolerable to fish culture and Bhatnagar et al. (2004) reported that the levels of temperature as $28-32{ }^{\circ} \mathrm{C}$ is ideal for tropical major carps. The observed water temperature in the water bodies can be considered as the normal for aquatic life in Council (S1), Ranimohal (S2), Chittagong Road(S3),East Mijmiji (S4), 
Signboard (S5), Afaz Nagar (S7) and Pagla (S8) sites except Lama Para (S6) site. In Lama Para, different type industrial waste directly release their effluents in the water. The temperature observed in this study supports the report of Boyd (1979) for good aquaculture practices.

Table1.Site-wise annual maximum, minimum and average values of physicochemical parameters of eight sampling sites of Dhaka-Narayanganj-Demra(DND) dam area water body with APHA (1989) values. Sites are denoted as $S(1-8)$ in the text.

\begin{tabular}{|c|c|c|c|c|c|c|c|c|c|c|c|}
\hline Name & Units & $\begin{array}{c}\text { Maximum- } \\
\text { Minimum } \pm \text { SE }\end{array}$ & $\begin{array}{l}\text { Council } \\
\text { (Site 1) }\end{array}$ & $\begin{array}{c}\text { Ranimohal } \\
\text { (Site 2) }\end{array}$ & $\begin{array}{l}\text { Chittagong } \\
\text { Road(Site 3) }\end{array}$ & $\begin{array}{c}\text { EastMijmiji } \\
\text { (Site 4) }\end{array}$ & $\begin{array}{c}\text { Signboard } \\
\text { (Site 5) }\end{array}$ & $\begin{array}{c}\text { Lama } \\
\text { Para (Site 6) }\end{array}$ & $\begin{array}{c}\text { Afaz Nagar } \\
\text { (Site 7) }\end{array}$ & $\begin{array}{l}\text { Pagla } \\
\text { (Site 8) }\end{array}$ & $\begin{array}{l}\text { APHA } \\
\text { (1989) }\end{array}$ \\
\hline Water & \multirow{2}{*}{$\left({ }^{\circ} \mathrm{C}\right)$} & Max-Min & $33-22$ & $31-20$ & $32-18$ & $31-18$ & $33-18$ & $37-31$ & $33-22$ & $33-21$ & Species \\
\hline Temperature & & Mean $\pm S E$ & $28 \pm 1.0$ & $27 \pm 1.0$ & $27 \pm 1.2$ & $26.3 \pm 1$ & $26.7 \pm 1.1$ & $34.6 \pm 0.4$ & $28.2 \pm 0.9$ & $27.5 \pm 10$ & depend \\
\hline \multirow[t]{2}{*}{ Transparency } & \multirow{2}{*}{$(\mathrm{cm})$} & Max-Min & $42-15$ & $39-12$ & $48-28$ & $15.5-7$ & $28-6$ & $8-6$ & $31-17$ & $39-13$ & Species \\
\hline & & Mean \pm SE & $28.7 \pm 2.2$ & $27.6 \pm 2.7$ & $40.3 \pm 0.8$ & $12 \pm 0.8$ & $13.8 \pm 1.9$ & $7.1 \pm 0.2$ & $21.5 \pm 1.2$ & $24 \pm 1.9$ & depend \\
\hline \multirow[t]{2}{*}{$\mathrm{pH}$} & & Max-Min & 7.8-7.1 & $7.8-7.1$ & $7.9-7.3$ & $7.9-7.0$ & $7.7-7.0$ & 8.3-7.1 & $8.4-7.6$ & 7.9-7 & Species \\
\hline & & Mean $\pm S E$ & $7.4 \pm 0.05$ & $7.4 \pm 0.05$ & $7.6 \pm 0.04$ & $7.4 \pm .05$ & $7.2 \pm 0.05$ & $7.7 \pm 0.1$ & $7.9 \pm 0.06$ & $7.5 \pm 0.09$ & depend \\
\hline \multirow[t]{2}{*}{ DO } & \multirow{2}{*}{ (mgL-1) } & Max-Min & $8.6-4.7$ & $11.9-5.2$ & $11.6-5.6$ & $8-4.6$ & $8.1-5.4$ & $9.8-5$ & $8.5-6.1$ & $8.9-5.1$ & \multirow{2}{*}{$>3.5$} \\
\hline & & Mean \pm SE & $6.9 \pm 0.3$ & $7.4 \pm 0.5$ & $7.6 \pm 0.4$ & $5.9 \pm 0.3$ & $7 \pm 0.2$ & $7.2 \pm 0.7$ & $7.2 \pm 0.2$ & $7.1 \pm 0.2$ & \\
\hline \multirow[t]{2}{*}{ Free $\mathrm{CO} 2$} & \multirow{2}{*}{ (mgL-1) } & Max-Min & $18.5-8.9$ & $32.5-9.8$ & $25-10.4$ & $115-21$ & $118-12.1$ & $119-50$ & $42-12.2$ & $44.5-12$ & \multirow{2}{*}{$<7$} \\
\hline & & Mean \pm SE & $11.9 \pm 0.8$ & $20 \pm 2.8$ & $17.4 \pm 1.4$ & $50.7 \pm 8$ & $44.5 \pm 9.5$ & $85.6 \pm 6.6$ & $21.5 \pm 2.6$ & $23.9 \pm 3$ & \\
\hline \multirow[t]{2}{*}{ Hardness } & \multirow{2}{*}{ (mgL-1) } & Max-Min & $170-36$ & $138-75$ & $156-120$ & $129-90$ & $138-93$ & $138-63$ & 153-114 & $948-213$ & \multirow{2}{*}{$>34.9$} \\
\hline & & Mean $\pm S E$ & $87.6 \pm 11$ & $102.7 \pm 5$ & $138.7 \pm 4.4$ & $144 \pm 2.8$ & $105.5 \pm 3$ & $107.7 \pm 5$ & $134.5 \pm 3.6$ & $491.2 \pm 76$ & \\
\hline
\end{tabular}

Transparency: Monthly maximum average transparency of water was $40.3 \pm 0.8 \mathrm{~cm}$ at Chittagong Road (S3) and minimum7.1 $\pm 0.2 \mathrm{~cm}$ in Lama Para (S6) (Table1, Fig. 3). Maximum seasonal mean transparency of eight sites was25.98 $\pm 4.32 \mathrm{~cm}$ in monsoon and minimum $18.27 \pm 2.88 \mathrm{~cm}$ in summer (Fig.3). The highest transparency was recorded $27.25 \pm 4.103 \mathrm{~cm}$ in August and lowest, $16.00 \pm 3.067 \mathrm{~cm}$ in April (Table 2).The average water transparency of East Mijmiji (S4),Signboard(S5) and Lama Para(S6) sites were very low due to industrial activity. Low transparency of water confines light penetration into it, limits photosynthesis and production of undesirable macrophytes in ponds (Boyd, 1979). Minimum Secchi depth i.e. high turbidity occurred in the Lama Para (S6) site was evidently due to iron mills, brick fields, stone breaking activities,

Table 2. Seasonal changes of average water parameters in Dhaka-Narayanganj-Demra (DND) dam area water bodie

\begin{tabular}{|c|c|c|c|c|c|c|c|}
\hline Seasons & Months & $\begin{array}{c}\text { Temperature } \\
\left({ }^{\circ} \mathrm{C}\right)\end{array}$ & $\begin{array}{c}\text { Transparency } \\
\text { (cm) }\end{array}$ & $\mathrm{pH}$ & $\begin{array}{c}\text { DO } \\
\text { (mgL-1) }\end{array}$ & $\begin{array}{c}\text { Free CO2 } \\
\text { (mgL-1) }\end{array}$ & $\begin{array}{l}\text { Hardness } \\
\text { (mgL-1) }\end{array}$ \\
\hline \multirow{4}{*}{ Summer } & Mar' 14 & $28.75 \pm 0.996$ & $19.50 \pm 3.513$ & $7.55 \pm 0.103$ & $6.54 \pm 0.355$ & $25.64 \pm 5.14$ & $150.13 \pm 20.39$ \\
\hline & Apr '14 & $30.38 \pm 0.728$ & $16.00 \pm 3.067$ & $7.53 \pm 0.133$ & $7.25 \pm 0.238$ & $21.15 \pm 4.44$ & $133.13 \pm 12.27$ \\
\hline & May'14 & $31.75 \pm 0.765$ & $17.94 \pm 2.649$ & $7.59 \pm 0.137$ & $7.76 \pm 0.673$ & $20.41 \pm 5.06$ & $123.00 \pm 17.07$ \\
\hline & Jun '14 & $28.25 \pm 0.552$ & $19.63 \pm 2.304$ & $7.63 \pm 0.148$ & $7.40 \pm 0.379$ & $21.39 \pm 6.94$ & $121.50 \pm 19.30$ \\
\hline \multirow{4}{*}{ Monsoon } & Jul '14 & $31.88 \pm 0.449$ & $26.06 \pm 3.681$ & $7.48 \pm 0.104$ & $7.45 \pm 0.647$ & $23.46 \pm 9.03$ & $123.00 \pm 22.43$ \\
\hline & Aug '14 & $31.00 \pm 0.468$ & $27.25 \pm 4.103$ & $7.46 \pm 0.127$ & $7.63 \pm 0.447$ & $25.84 \pm 9.56$ & $136.13 \pm 43.25$ \\
\hline & Sep'14 & $31.50 \pm 0.848$ & $24.63 \pm 4.286$ & $7.55 \pm 0.127$ & $8.05 \pm 0.286$ & $34.23 \pm 10.21$ & $202.88 \pm 84.96$ \\
\hline & Oct' 14 & $28.63 \pm 0.900$ & $26.00 \pm 5.193$ & $7.51 \pm 0.089$ & $7.50 \pm 0.235$ & $43.49 \pm 10.90$ & $212.63 \pm 96.23$ \\
\hline \multirow{4}{*}{ Winter } & Nov'14 & $25.13 \pm 1.280$ & $24.00 \pm 5.232$ & $7.58 \pm 0.061$ & $7.23 \pm 0.598$ & $53.06 \pm 11.70$ & $216.38 \pm 98.12$ \\
\hline & Dec'14 & $23.00 \pm 1.500$ & $21.50 \pm 4.988$ & $7.66 \pm 0.092$ & $6.13 \pm 0.415$ & $60.08 \pm 14.06$ & $179.63 \pm 60.62$ \\
\hline & Jan' 14 & $22.13 \pm 1.754$ & $20.63 \pm 3.925$ & $7.71 \pm 0.096$ & $5.78 \pm 0.308$ & $47.95 \pm 10.97$ & $162.75 \pm 37.47$ \\
\hline & Feb '14 & $26.75 \pm 1.247$ & $20.00 \pm 3.575$ & $7.48 \pm 0.093$ & $6.18 \pm 0.226$ & $34.24 \pm 7.64$ & $162.25 \pm 30.54$ \\
\hline
\end{tabular}


garments factory, dying factory situated in this area. Water from the different spots varies in solids concentrations depending on the volume of mineralization, amount of suspended clay and abundance of plankton (Boyd, 1992). According to Bhatnagar et al. (2004) transparency range from $30-80 \mathrm{~cm}$ is good for fish health; $15-40 \mathrm{~cm}$ is good for intensive culture system and $<12 \mathrm{~cm}$ causes stress. The transparency values in DND canal are within the desirable range for the fish production.

$p H$ : The maximum average $\mathrm{pH}$ of water was recorded $7.9 \pm 0.06$ at Afaz Nagar (S7), and the minimum7.2 \pm 0.05 was in Signboard (S5) (Table 1, Fig. 4).The $\mathrm{pH}$ of water in DND canal areas agrees with the desirable lower limit for aquaculture. The maximum $\mathrm{pH}$ was $7.61 \pm 0.086$ in winter and minimum $7.5 \pm 0.11$ in monsoon. The highest $\mathrm{pH}$ was recorded $7.71 \pm 0.096$ in January and lowest, $7.46 \pm 0.0127$ in August (Table 2). The water in all areas appeared slightly basic in nature. According to Roule (1930) the largest fish crops are usually produced in alkaline side of neutrality between $\mathrm{pH} 7.0$ and 8.0. Ohle et al. (1938) reported that any $\mathrm{pH}$ value lower than $\mathrm{pH} 4.8$ or higher than $\mathrm{pH} 10.8$ might bring noxious effects to the aquatic organisms. In the present study it was observed that the DND canal water had a pH more than 7.0 and most of the canal had a $\mathrm{pH}$ between 7.1 and 7.9. This is generally the normal range of $\mathrm{pH}$ in freshwater canal unless contaminated by base. Huet (1986) observed that $\mathrm{pH}$ values of 6.5 to 9.0 are good for fish production, hence the DND canal water are appeared more conducive.

Dissolved oxygen (DO): The concentration of average DO decreased gradually from September to January (Table 2). It attained its maximum average value in Chittagong $\operatorname{Road}(\mathrm{S} 3) 7.6 \pm 0.4 \mathrm{mgL}^{-1}$ and then decreased till January when it attained its nearly minimum average value $5.9 \pm 0.3 \mathrm{mgL}^{-1}$ in Mijmiji (S4) (Table1, Fig. 5). Maximum seasonal mean DO was $7.65 \pm 0.40 \mathrm{mgL}^{-1}$ recorded in monsoon and minimum6.33 $\pm 0.39 \mathrm{mgL}^{-1}$ in winter (Fig. 8). The highest amount of DO was recorded $8.05 \pm 0.286 \mathrm{mgL}^{-1}$ in September and lowest $5.78 \pm 0.308 \mathrm{mgL}^{-}$ ${ }^{1}$ was in August (Table 2). There is no remarkable change in Lama Para(S6) because of industrial waste. According to APHA (1989) $3.5 \mathrm{mgL}^{-1}$ or above is suitable for fish culture. All sampling sites had desirable DO level for fish culture. 


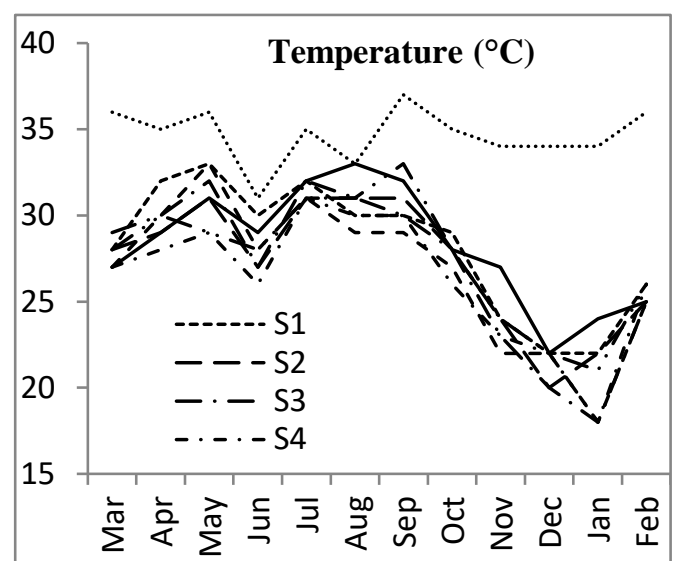

Fig. 2. Monthly water temperature

$\left({ }^{\circ} \mathrm{C}\right)$ in different sampling spots.

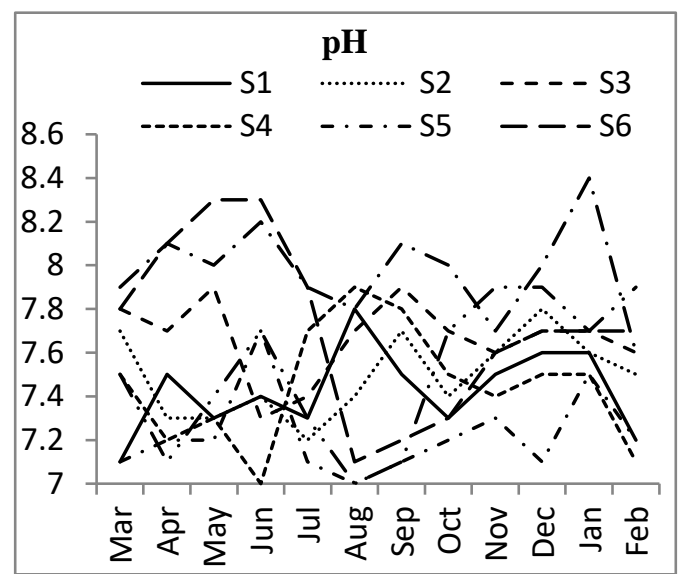

Fig. 4. Monthly $\mathrm{pH}$ of water at different sampling spots.

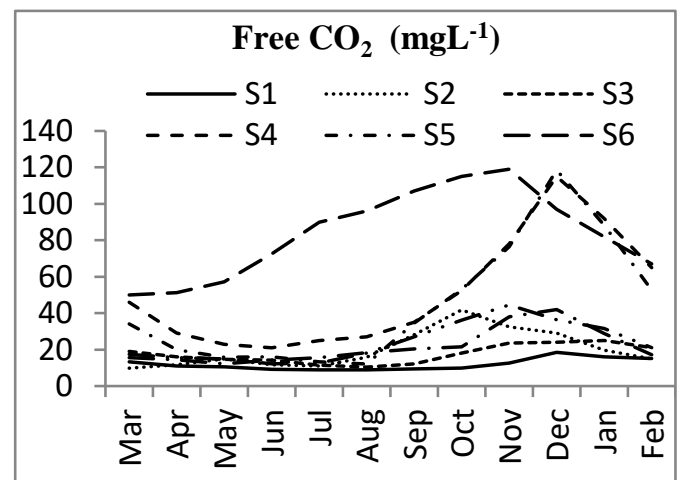

Fig. 6. Monthly free $\mathrm{CO}_{2}$ inwater at different sampling spots.

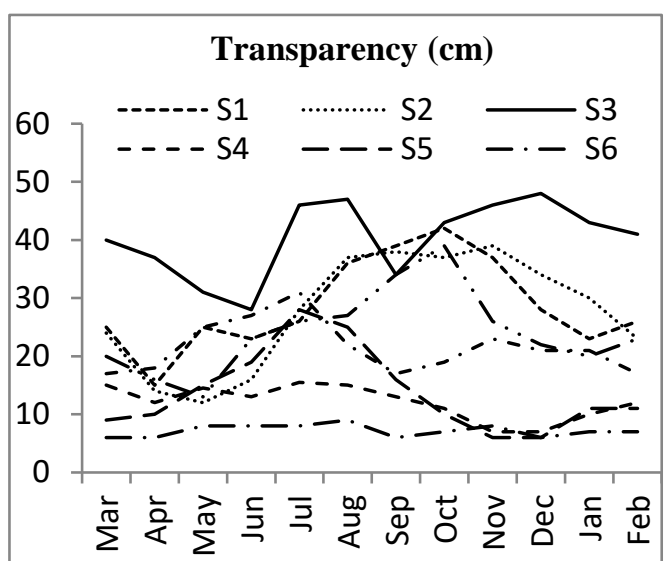

Fig. 3. Monthly transparency of water $(\mathrm{cm})$ in different sampling spots.

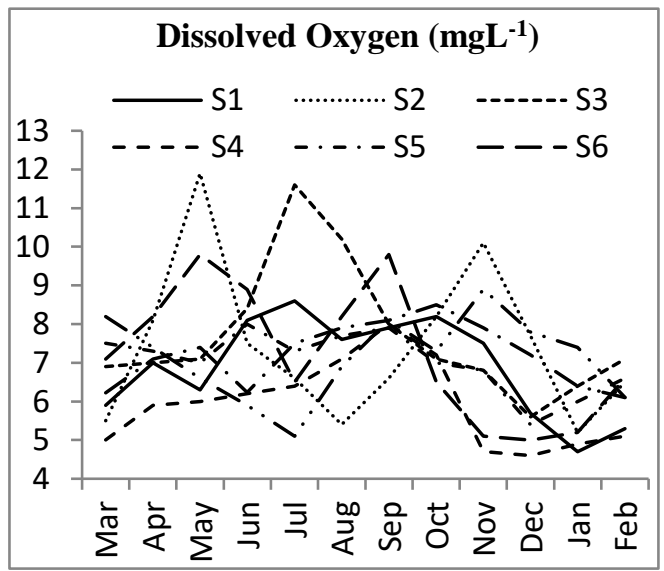

Fig. 5. Monthly dissolved oxygen $\left(\mathrm{mgL}^{-1}\right)$ of water at different sampling spots.

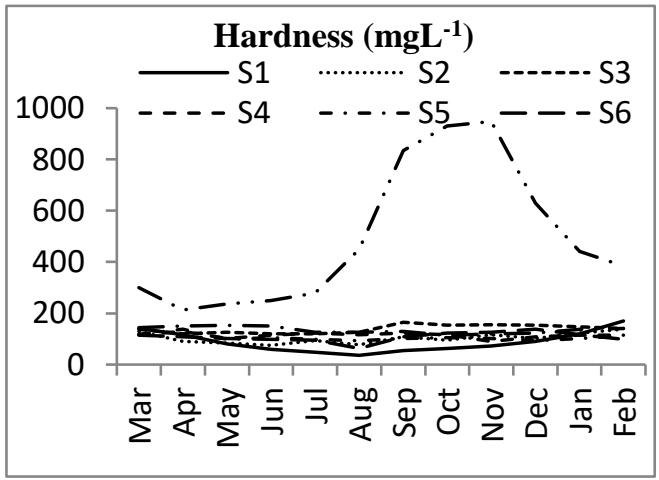

Fig. 7. Monthly hardness $\left(\mathrm{mgL}^{-1}\right)$ of water at different sampling spots. 


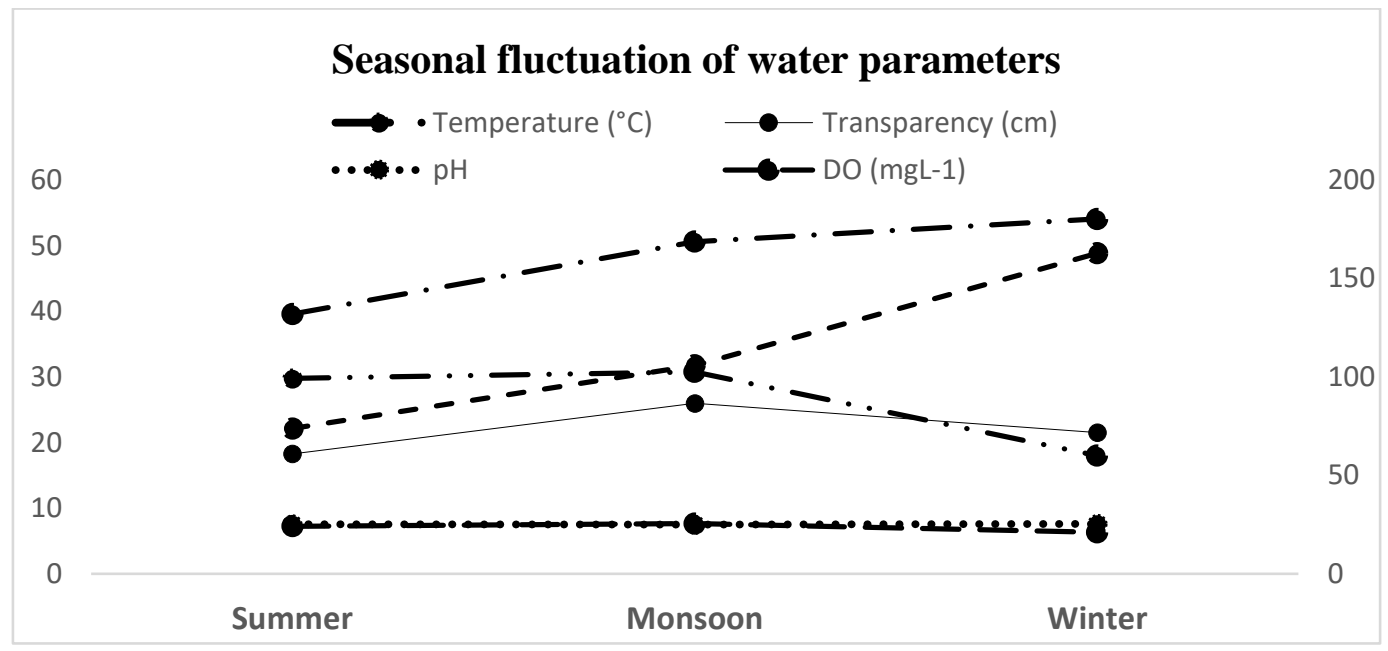

Fig. 8. Seasonal fluctuation of average values of water parameters in DhakaNarayanganj-Demra (DND) dam area water bodies (Hardness on secondary axis).

Free carbon dioxide $\left(\mathrm{CO}_{2}\right)$ : Minimum average free $\mathrm{CO}_{2}$ of water at different sampling sites was $11.9 \pm 0.8 \mathrm{mgL}^{-1}$ which was recorded in Council (S1) while the maximum was $85.6 \pm 6.6 \mathrm{mgL}^{-1}$ in Lama Para (S6)(Table1, Figure 6). Seasonally, maximum mean value of free carbon dioxide was $48.83 \pm 11.09 \mathrm{mgL}^{-1}$ in winter and minimum was $22.14 \pm 5.39 \mathrm{mgL}^{-1}$ in summer (Fig. 8). The highest free $\mathrm{CO}_{2}$ was recorded $60.08 \pm 14.06 \mathrm{mgL}^{-1}$ in December and lowest $20.41 \pm 5.06 \mathrm{mgL}^{-1}$ in May (Table 2).Most of the sites showed average free $\mathrm{CO}_{2}$ higher than $11.9 \mathrm{mgL}^{-}$ 1.Almost throughout the year a gradual increase in free $\mathrm{CO}_{2}$ with decreasing of water level as well as increasing of sewage, garbage, waste materials of mills and factories was observed. The free $\mathrm{CO}_{2}$ in water promoting good fish population and the value should be less than $5 \mathrm{mgL}^{-1}$ (Santhosh and Singh, 2007). On the basis of Boyd and Lichtkoppler (1979) fish stay away from free $\mathrm{CO}_{2}$ levels as low as $5 \mathrm{mgL}^{-1}$ but most species can sustain in waters containing up to $60 \mathrm{mg} \mathrm{L}^{-}$ ${ }^{1} \mathrm{CO}_{2}$.According to Ekubo and Abowei (2011) fishes can endure $\mathrm{CO}_{2}$ levels over $100 \mathrm{mgL}^{-1}$ but the optimum level of $\mathrm{CO}_{2}$ in is less than $10 \mathrm{mgL}^{-1}$.It may depends upon alkalinity and hardness of water body. The value of $\mathrm{CO}_{2}$ was high in December. This may be due to the high rate of decomposition in the warmer months. Khan and Chowdhury (1990) reported that higher $\mathrm{CO}_{2}$ occurred during winter season (December) due to absence of rain, runoff and flood water as well as gradual settling of suspended particles. Habib et al. (2013) also reported similar observation from around DND dam area.

Hardness: Maximum average hardness of water found $491.2 \pm 76 \mathrm{mgL}^{-}$ ${ }^{1}$ atPagla (S8) while the minimum was $87.6 \pm 11.3 \mathrm{mgL}^{-1}$ (Table1, Fig. 7) at Council (S1).The highest value948 $\mathrm{mgL}^{-1}$ of hardness was observed at Pagla (S8) in April and the lowest $213 \mathrm{mgL}^{-1}$ in November (Fig. 7).Hardness of water at Pagla was 
found always at the highest among all other sites. The highest hardness was recorded 216.38 $\pm 98.12 \mathrm{mgL}^{-1}$ in November and lowest $121.50 \pm 19.30 \mathrm{mgL}^{-1}$ in June (Table 2). During the study maximum hardness was recorded $180.25 \pm 56.69 \mathrm{mgL}^{-1} \mathrm{in}$ winter and minimum $131.94 \pm 17.26 \mathrm{mgL}^{-1}$ in summer. Both the values are far away from the standard value of hardness of water for fish culture. The result is slightly differ with Habib et al(2013) because in recent years there are many industrial development occurred for example iron mills, brick fields, stone breaking fields, garments factory, dying factory are established in this area. These mills and factories are releasing different type of pollutants and active chemicals, debris, dust, wastes to the water. Also the road and the adjacent area has heavy traffic most time of day which adds black smoke, harmful gases like $\mathrm{CO}_{2}, \mathrm{CO}, \mathrm{SO}_{2}, \mathrm{NO}_{2}$ etc and a remarkable part of this component back in water body by rain or settling. On the other hand most of the dwellers of this area are dumping garbage here and there, especially near the water body. Fish species has their own range of water hardness for existence.

Prospects of fish culture in the wetlands: Good fish culture depends largely on the quality of water which is a complex interaction of different physical, chemical and biological, ecological factors of the water body. DND dam is a much populated area in and adjacent to the capital city. The area is hampered by the over populated activity. Also tolerance of fish to the factors of the water is not always equal for all fish. Some could live in even hard and hot water and most fish has their own specific range. Tolerance to a factor is mostly species dependent. Physical, chemical and biological water parameters influence the gross production of water bodies. Favourable range of water parameters results in the high production of aquatic organisms. Fifty percent of the sites were found in favourable in terms of water temperature. Water temperature at Lama Para found beyond the limit for common fishes. So, temperature may not be an obstacle for fish culture in the area. $30-80 \mathrm{~cm}$ transparency of water is good for fish (Bhatnagar et al (2004) which was found in favour in most places at rainy season and onwards except in Lama Para. The place found industrially rich compared to other spots. Dry season may not be in favour to fish culture when most of the area became dry and water is limited to deeper areas only. Transparency found good to fish culture. Another factor is pH.6.5 - 9.0 pH value is favourable for fish (Huet 1986). None of the studied area was found exceed the limit of $\mathrm{pH}$. So, in terms of $\mathrm{pH}$ value the area is suitable for fish culture. Probably the most important factor for aquatic organism is DO which was found in the study area more or less within the limit. Favourable DO values for fisheries ranged from 4 to $6 \mathrm{mgL}^{-1}$ (Boyd, 1990), below which most cultivable aquatic organisms could not sustain or have good growth. APHA (1989) recommend $3.5 \mathrm{mgL}^{-1}$ or more is favourable for fish culture. DO level was found in safe in all the spots of DND area. Ideal level of free $\mathrm{CO}_{2}$ in fish ponds is less than $10 \mathrm{mgL}^{-1}$ (Ekubo and Abowei, 2011). But Santhosh and Singh (2007) reported that the amount of free $\mathrm{CO}_{2}$ in water should be less than $5 \mathrm{mgL}^{-1}$. Boyd and Lichtkoppler (1979) reported that fish keep away themselves from free $\mathrm{CO}_{2}$ levels as low as 5 , but most fishes can tolerate waters containing $60 \mathrm{mgL}^{-1}$. Although maximum amount of $\mathrm{CO}_{2}$ in all spots exceeds the tolerable limit but 
this factor found favourable most of the time in the year. So, free $\mathrm{CO}_{2}$ in the area except Lama Para is under control for fish culture. APHA (1989) recommended value for hardness of water is higher than $34.9 \mathrm{mgL}^{-1}$ which was found round the year in all spots suitable for fish culture in the area. The study suggest the area is in favour to fish culture.

Other environmental factors needed to be studied in this area before fish culture. The area may regarded as polluted and pollution occurred mostly by releasing of huge amount of human-produced garbage, litters, trash, debris, metallic and industrial wastes day by day. Most water parameters in DND canal were found to be suitable for fish culture but some parameters at a distinct point was not found healthy for fish culture and it was evident that DND is organically a little bit polluted. But present study suggests that the area is still in favourable for fish culture. Further extensive investigation on biological, ecological study with heavy metal pollution may needed this area. Some physical and chemical water parameters were studied in that area and recommendation was made only on the result found in the study. Further extensive physical, chemical and biological aspect of the water bodies should be new horizon to be studied. In addition, the post-harvest meat quality of fish should be considered for further study.

\section{LITERATURE CITED}

APHA-AWWA-WPCF,1989. Standard methods for the examination of water and wastewater. New York: American Public Health Association.

BANGLAPEDIA,2006. National Encyclopaedia of Bangladesh, Asiatic Society of Bangladesh.

BBS, Bangladesh Bureau of Statistics, Annual Report 2015.

BHATNAGAR, A., JANA, S.N., GARG, S.K., PATRA, B.C., SINGH, G. and BARMAN, U.K. 2004. Water quality management in aquaculture, In Course Manual of summer school on development of sustainable aquaculture technology in fresh and saline waters, CCS Haryana Agricultural, Hisar (India), pp 203-210.

BOYD, C.E and LICHTKOPPLER, F. 1979. Water quality management in fish ponds. Research and development series No. 22, International centre for aquaculture (J.C.A.A) Experimental station Auburn University, Alabama, pp 45-47.

BOYD, C.E. 1990. Water quality in ponds for aquaculture. Ala. Agr. Exp. Sta. Auburn University. $462 p$.

BOYD, C.E. and TUCKER, C.S. 1992. Water quality and pond soil analyses for aquaculture. Alabama agricultural experiment station, Auburn University, Alabama, pp.183.

DELINCE, G. 1992. The ecology of the fish pond ecosystem: with special reference to Africa, Kluwer Academic Publishers London, pp 230.

DEEPAK, S. and SINGH,U. N. 2014. The relationship between Physico-chemical Characteristics and Fish Production of Mod Sagar Reservoir of Jhabua District, MP, India,3, pp-82-86.

DoE,1993. Environmental quality standard for Bangladesh, Ministry of Environment and Forestry, Department of Environment, Dhaka, Bangladesh, pp-25.

EHIAGBONARE J.E. and OGUNDIRAN Y.O. 2010. Physico-chemical analysis of fishpond waters in Okada and its environs, Nigeria. African J. Biotech., 9(36), 5922-5928.

EKUBO, A.A. and ABOWEI, J.F.N. 2011. Review of some water quality management principles in culture fisheries, Research Journal of Applied Sciences, Engineering and Technology, 3(2),pp 1342-1357.

KHAN, M. A. G and CHOUDHARY S.H. 1990. Physical and chemical limnology of lake Kaptai: Bangladesh, Tropical Ecology, 35(1), pp 35-51. 
HABIB, A.H.M SHAFIULlAH., ALAM M. MAHABUB. And NASER, M. NIAMUL. 2013. Suitability of the west led Dhaka-Narayanganj-Demra (DND) dam canal for water the aquaculture practices, Jagannath University, Journal of Science, Volume-2, Number-1, pp 33-38.

HARGIS, L. G. 1988. Analytical Chemistry; Prentice, New Jersey, pp179-181.

HUET, M. 1986.Textbook of fish culture 2nd Edn. Fish News Book Ltd. England. Vide Study on the Physico-chemical properties of water of Mouri River, Khulna Bangladesh, Pak. J. Biol. Sci. 10(5), 710-717.

KOCAOBA, S. and AKCIN, G. 2005.Desalination, 180, 151.

OHLE, W. 1938.TeichwirtschafthcheKalkkontrolle und die pH-SBV-Tasche (Control of liming in ponds with an outfit for $\mathrm{pH}$ and alkalinity determination). Z. Fisch. 36: 185-191.

PATRA, R.W.R. and AZADI, M.A. 1987. Ecological studies on the planktonic organisms of the Halda River, Bangladesh J. Zool. 15(2):109-123.

ROULE, L. 1930. pH determination in the evaluation of carp ponds. C. R. Acad. Agri. France, 16: 1056-1060.

SANTHOSH, B. and SINGH, N.P. 2007. Guidelines for water quality management for fish culture in Tripura, ICAR research complex for NEH region, Tripura Center, Publication no.29.

VIESSMAN,W. and HAMMER, M.J. 1998. Water supply and pollution control, 5th edn. Harper Collins College Publishers, New York.

(Manuscript received on 20 November, 2019 revised on 20 February, 2020) 